\title{
Role of hydrology in development of a vernal clear water phase in an urban impoundment
}

\author{
JOHN T. LEHMAN, RACHEL A. PLATTE AND JULIE A. FERRIS \\ Department of Ecology and Evolutionary Biology, Natural Sciences Building, University of Michigan, Ann Arbor, MI, U.S.A.
}

\begin{abstract}
SUMMARY
1. Grazer control of phytoplankton and water transparency was responsive to interannual variations in river discharge and corresponding water retention time in Ford Lake, Michigan, U.S.A.

2. A simple mathematical model was developed to separate the effects of washout from in situ zooplankton population dynamics. The threshold reservoir flushing time for development of a large Daphnia population and corresponding clear water phase during May was about 20 days. Predation by Leptodora was insufficient to cause the subsequent decline of the Daphnia population.

3. Recruitment success by the zebra mussel Dreissena polymorpha appeared responsive to flushing time indirectly, through hydrological effects on the magnitude of the spring diatom crop.
\end{abstract}

Keywords: Dreissena recruitment, herbivory, impoundment, interannual variability, threshold response

\section{Introduction}

Water residence time has long been known to be a key factor in the establishment of resident zooplankton communities in coastal estuaries (Deevey, 1960). Long flushing times permit the development of distinctive estuarine populations, whereas short flushing times prevent such development. The same principles presumably apply to freshwater riverine impoundments, and water retention time of reservoirs is indeed known to be an influential factor (Straškraba, 2005). A key consideration would seem to be whether the flushing rates are significant in magnitude compared with typical zooplankton birth rates. Owing to interannual variation in river flow, it is possible that hydrology can work as a master variable, enabling or disabling net rates of population growth by both

Correspondence: John T. Lehman, Department of Ecology and Evolutionary Biology, Natural Sciences Building, University of Michigan, Ann Arbor, MI 48109-1048, U.S.A.

E-mail: jtlehman@umich.edu phytoplankton and zooplankton, and thus affecting seasonal succession.

In a recent study, Ferris \& Lehman (2007) demonstrated strong hydrologic control on spring diatom dynamics in an urban impoundment, and they used this control to alter the phytoplankton community through whole lake manipulation. Here, we intend to show that the general principles that affect interannual size of the diatom crop can be extended to zooplankton populations and magnitudes of herbivory, to such a degree that development of a springtime period of biologically-induced exceptional water transparency is a predictable consequence of hydrologic pattern.

As climatic patterns continue to change during this century, any transformational role played by seasonal hydrology could instigate nonlinearities in ecosystem response to climate change. It seems reasonable, therefore, to develop a theoretical context for evaluating these effects. We selected a man-made basin with a ratio of mean water throughput to total volume that is $<10 \%$ per day, but variable year to year, to study the influence of this variability on phytoplankton and zooplankton populations. 


\section{Methods}

\section{Site description}

Ford Lake is an impoundment of the Huron River in southeastern Michigan, U.S.A. $\left(42.21^{\circ} \mathrm{N}, 83.56^{\circ} \mathrm{W}\right)$ that was constructed by Henry Ford in 1932 to supply hydroelectric power to his Motor Company. The lake has a surface area of $4.039 \mathrm{~km}^{2}$ and mean depth of $4.3 \mathrm{~m}$; its maximum depth is $11 \mathrm{~m}$ at the outlet dam. It drains an upstream catchment area of $1280 \mathrm{~km}^{2}$, giving it a ratio of catchment area to surface area of 317 , considerably greater than the mean ratio of $14: 1$ cited by Thornton, Kimmel \& Payne (1990) for reservoirs in general. There are no large impoundments or natural lakes immediately upstream, but the lake's phytoplankton and zooplankton communities are limnetic. The local catchment is urbanized, and the City of Ann Arbor maintains the outfall from its municipal wastewater treatment facility several $\mathrm{km}$ upstream of the lake inlet. The lake typically becomes thermally stratified in the first week of May, although temperature differences across the thermocline are usually only 3 or $4{ }^{\circ} \mathrm{C}$. The impoundment is operated as 'run of the river', meaning that stage heights are tightly regulated so that outflow matches inflow. From January 2003 to November 2006 the mean flushing time (lake volume divided by discharge) was 13 days, and ranged from 3 to 54 days.

The lake develops vernal diatom blooms that vary in abundance from year to year, and which have been attributed to interannual variations in hydrology during April (Ferris \& Lehman, 2007). The lake also develops large populations of Daphnia mendotae Hebert and a conspicuous clear water phase (Lampert, 1978) in some years but not others. During August the lake becomes dominated by thick nuisance blooms of Aphanizomenon and Microcystis, with elevated levels of microcystin (Lehman, 2007). The zebra mussel Dreissena polymorpha Pallas colonized the lake in the 1990s; adults spawn in May and June.

\section{Hydrology}

Daily discharge at the hydroelectric dam $(Q$, $\mathrm{m}^{3}$ day $^{-1}$ ) was obtained from the operator's logbook (M. Saranen, Ypsilanti Charter Township, pers. comm) for 2003-06. Historical daily discharge of the Huron River at Ann Arbor was obtained from United States Geological Service (USGS) on-line archives for

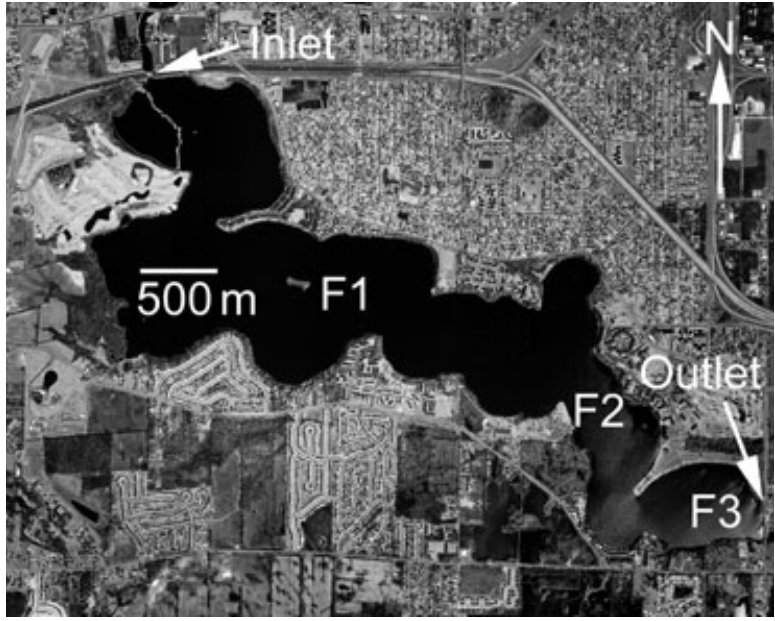

Fig. 1 Ford Lake with inlet, outlet and sampling stations identified. Shown is the red channel of a colour infrared digital orthophoto taken by the USGS on 25 April 2000.

station 04174500 . Station 04174500 is upstream from Ford Lake and river flow entering the lake is $21 \%$ greater than that measured at the long-term USGS gaging site (Ferris \& Lehman, 2007).

\section{Water transparency and chlorophyll-a}

Water transparency was measured with a plain white Secchi disc $20-\mathrm{cm}$ in diameter at three stations identified as F1, F2 and F3 in Fig. 1. Raw water for pigment analysis was collected by integrative tube sampler from 0 to $5 \mathrm{~m}$ depth at the same sites. Chlorophyll- $a$ (chl) was measured as extracted fluorescence using GF/C filters, 90\% v/v acetone, a tissue grinder and a TD700 fluorometer (Turner Designs, Sunnyvale, CA, U.S.A.). We tested the hypothesis that interannual differences exist lake-wide in a critical period from 20 May to 15 June, using paired $t$-tests applied to data from corresponding stations during corresponding weeks of each year.

\section{Zooplankton abundance}

Zooplankton were collected weekly from May to September of 2004, 2005 and 2006 by vertical tows of a conical net with $30-\mathrm{cm}$ mouth diameter, $1: 5$ aspect ratio and $64-\mu \mathrm{m}$ mesh aperture. The reference sampling site was at 10-m depth near the outlet dam (site F3 in Fig. 1). In 2005, an additional site at 8-m depth was also sampled (site F2 in Fig. 1). Quantitative subsamples were counted for cladocerans, copepods and 
Daphnia eggs or embryos; entire samples were searched for Leptodora kindti Focke, because this invertebrate predator was present at much lower abundance than its herbivore prey.

Veliger larvae of $D$. polymorpha were counted by compound microscope at $188 \times$ magnification using a Sedgewick-Rafter cell. Sample volumes were adjusted to $100 \mathrm{~mL}$ and $1-\mathrm{mL}$ aliquots were dispensed to the counting cell. When veligers were abundant, random fields were searched and counted; when veligers were rare, the entire counting cell was searched systematically.

\section{Daphnia size frequency and egg age distributions}

Samples were inspected to identify the minimum sizes of ovigerous Daphnia. Lengths were measured by optical micrometer from midpoint of the eye to the base of the tailspine. Size frequency distributions were constructed by measuring a minimum of 30 individuals, if present. Chi-squared analyses were performed on frequencies of juveniles and adults over time to learn if the populations achieved stable age structure.

Egg age distributions were examined in 2005 to determine if egg inviability or egg mortality might be a factor in population dynamics. On each date, more than 100 eggs were examined microscopically and were classified as 'egg' or 'embryo' depending on whether or not cleavage and embryonic differentiation were present (Hoffman, Smith \& Lehman, 2001). Statistically significant (chi-squared test) decreases in proportions of embryos would be considered evidence of potential egg mortality.

\section{Birth rate estimates and population growth rates for} Daphnia

Edmondson's finite birth rate $B$ was calculated as $B=$ $E / D$ where $E$ is egg ratio (i.e. mean eggs or embryos per female) and $D$ is development time (days) according to Edmondson \& Litt (1982):

$$
\frac{1}{D}=0.000411 T^{2}+0.0108 T-0.0163
$$

where $T$ was calculated as the mean temperature from 0 to $7 \mathrm{~m}$ depth. Our preliminary sampling had established that hypoxic conditions below $7 \mathrm{~m}$ excluded Daphnia from the region.
The rate of change of Daphnia abundance was assumed to be the net difference of recruitment by birth or hatching of resting eggs, mortality and outwash.

$$
\frac{\mathrm{d} N}{\mathrm{~d} t}=(r-\tau) N
$$

where $r$ is net intrinsic growth rate (recruitment minus mortality, day ${ }^{-1}$ ), and $\tau$ is washout rate defined as $Q / V$ where $Q$ is discharge $\left(\mathrm{m}^{3}\right.$ day $\left.^{-1}\right)$ and $V$ is lake volume $\left(\mathrm{m}^{3}\right)$. Eqn. 2 was integrated on a daily basis, using empirical values for daily $Q$ :

$$
N(t+1)=N(t) \exp \left(r-\tau_{t}\right)
$$

where $N(t+1)$ represents population size 1 day after time $t$. Intrinsic growth rate $r$ was assumed constant between sampling dates and was calculated explicitly by solving across sampling dates using the product of daily iterations of eqn (3) from initial date $(t)$ to the next sampling date $(\Delta t)$ :

$$
r=\ln \frac{[N(t+\Delta t) / N(t)]}{\Delta t}-\ln \left[\prod_{t}^{\Delta t} \exp \left(-\tau_{i}\right)\right]
$$

Flushing time $\left(T_{\mathrm{f}}\right)$ was calculated using $Q$ and lake volume $\left(V=17370000 \mathrm{~m}^{3}\right)$. For any given arbitrary starting day, designated $t=0, T_{\mathrm{f}}$ was calculated from the implicit function given in eqn (5).

$$
V=\int_{0}^{T_{\mathrm{f}}} Q \mathrm{~d} t
$$

The approach represented by eqns (2)-(4) was also applied to Dreissena veligers. In the case of the zebra mussels, $r$ was considered to represent the net balance of veliger production (i.e. recruitment from trochophore larvae), in situ mortality and rate of settling from planktonic larval stage to sessile benthic stage.

\section{Predation by Leptodora}

We tested the hypothesis that predation by Leptodora was sufficient to account for the population decline of D. mendotae following its peak in May 2005. We formulated a model in which the predicted rate of change in numbers of $D$. mendotae on any given day $i$ $\left(\mathrm{d} N_{i} / \mathrm{d} t\right)$ was the net balance of birth, outwash and predation: 


$$
\frac{\mathrm{d} N_{i}}{\mathrm{~d} t}=\left(B_{i}-\tau_{i}\right) N_{i}-p L_{i}
$$

where $L_{i}$ is Leptodora abundance (individuals $\mathrm{m}^{-2}$ ) on day $i$ and $p$ is predation rate (Daphnia killed per Leptodora per day). We interpolated finite birth rate $B$ and Leptodora abundance $L$ linearly between sample dates and integrated eqn (6) iteratively, 1 day at a time, such that

$$
N_{i+1}=\frac{\left[\left(B_{i}-\tau_{i}\right) N_{i}-p L_{i}\right] \exp \left(B_{i}-\tau_{i}\right)+p L_{i}}{B_{i}-\tau_{i}}
$$

Predation rate $p$ was held constant between sample dates. Iterative application of eqn (6) generated a daily series of hypothetical Daphnia abundances $N(i)$ between one sample date and the next. We solved the resulting implicit function for $p$ using the 'Solver' function of Excel ${ }^{\mathrm{TM}}$ (Microsoft Corporation, Redmond, WA, U.S.A.) such that the predicted Daphnia abundances on sample dates matched the empirical data.

\section{Fish stomach contents}

On 3 June 2005, between 10:30 and 11:30 hours local time, three specimens of bluegill (Lepomis macrochirus Rafinesque) and three specimens of white bass (Morone chrysops Rafinesque) were collected by angling near the outlet dam. The fish were weighed, their stomachs immediately placed in ethanol and stomach contents were subsequently examined.

\section{Results}

The spring Daphnia fauna of Ford Lake in 2004 and 2005 was dominated by D. mendotae, but that species did not develop well in 2006, and Daphnia retrocurva Forbes appeared in June. May through June was the time of greatest Daphnia abundance each year, and these abundances as well as Secchi disc transparency depth and lake flushing times are depicted in Fig. 2. It is evident that the clear water phase of 2005 was associated with elevated abundance of $D$. mendotae and with flushing times exceeding 20 day.

\section{Secchi and chlorophyll-a}

Secchi disc transparency measured at sites F1, F2 and F3 (Figs 1 \& 3) was significantly greater during the critical period from 20 May to 15 June of 2005

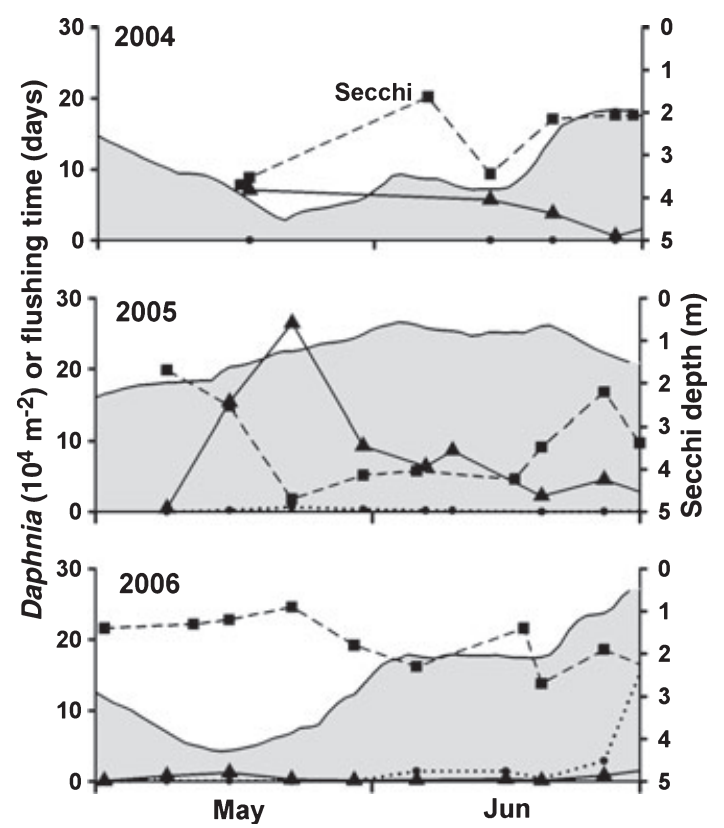

Fig. 2 Secchi disc transparency depth (squares and dashed lines), abundance of Daphnia mendotae (triangles and solid lines) and Daphnia retrocurva (dotted lines) during May and June of 2004, 2005 and 2006. Flushing time (eqn. 5) is shown as shaded areas.

compared with both $2004(P=0.0001)$ and 2006 $\left(P=3 \times 10^{-7}\right)$. The years 2004 and 2006 were not significantly different $(P=0.99)$.

Chlorophyll- $a$ concentrations lake-wide were indistinguishable among years $(P>0.11$ for all pairwise contrasts), an observation that appears to trace entirely to higher levels of chl at station F3 compared with F1 and F2 during 2005 (Fig. 4).

\section{Daphnia size frequency and egg age distributions}

The minimum size of ovigerous females for both D. mendotae and D. retrocurva was $1 \mathrm{~mm}$. Table 1 reports the proportions of juveniles in the Daphnia population on different dates. Chi-squared goodnessof-fit analysis was applied separately for each year and at each sampling site in 2005. The results revealed that stable age structure (i.e. constant proportions of juveniles to adults) was not achieved in any year or site for D. mendotae ( $P \leq 0.002$ in all cases), nor for $D$. retrocurva during June $2006(P=0.04)$.

Potential bias in birth rate estimates from egg mortality or inviability during 2005 was undetectable by our a priori criteria. The proportion of total eggs and embryos represented by embryos was $63 \%$ and 

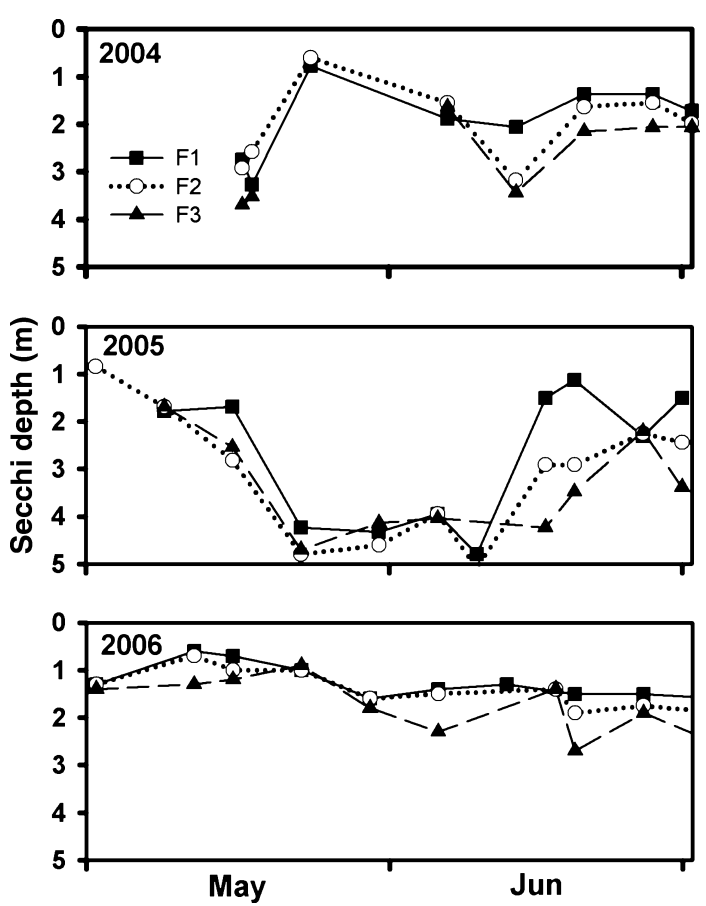

Fig. 3 Secchi disc transparency at three sampling sites during May and June of 2004, 2005 and 2006.
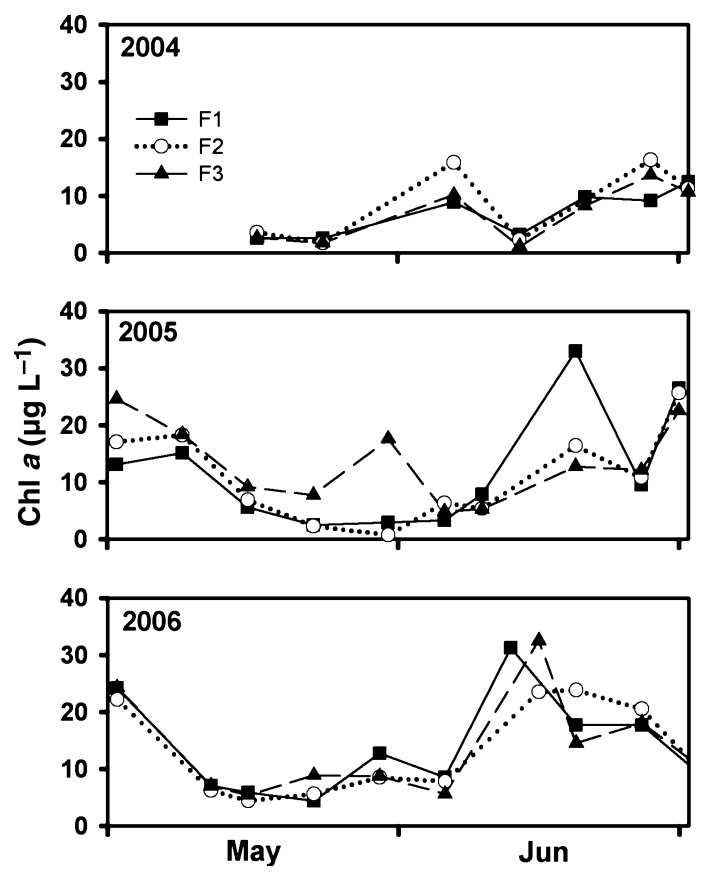

Fig. 4 As Fig. 3, but for chlorophyll- $a$.

$39 \%$, respectively, at F2 and F3 during the increasing period of Daphnia abundance (16 May). During the period of decreasing abundance (10 and 20 June),
Table 1 Sample sizes $(n)$ used for size-frequency analyses and proportions of the populations that were juveniles (Juv)

\begin{tabular}{llll}
\hline Date & Site & $n$ & Juv \\
\hline 18 May 04 & F3 & 45 & 0.800 \\
14 Jun 04 & F3 & 30 & 0.533 \\
21 Jun 04 & F3 & 45 & 0.244 \\
28 Jun 04 & F3 & 30 & 0.467 \\
9 May 05 & F2 & 14 & 0.643 \\
16 May 05 & F2 & 75 & 0.707 \\
16 May 05 & F3 & 75 & 0.960 \\
23 May 05 & F2 & 73 & 0.849 \\
23 May 05 & F3 & 75 & 0.933 \\
31 May 05 & F2 & 30 & 0.433 \\
31 May 05 & F3 & 30 & 0.867 \\
6 Jun 05 & F2 & 30 & 0.700 \\
6 Jun 05 & F3 & 30 & 0.967 \\
10 Jun 05 & F2 & 30 & 0.233 \\
10 Jun 05 & F3 & 30 & 0.833 \\
20 Jun 05 & F2 & 30 & 0.733 \\
20 Jun 05 & F3 & 30 & 0.667 \\
27 Jun 05 & F2 & 30 & 0.867 \\
27 Jun 05 & F3 & 30 & 0.900 \\
2 May 06 & F3 & 30 & 0.967 \\
9 May 06 & F3 & 30 & 0.567 \\
16 May 06 & F3 & 30 & 0.833 \\
23 May 06 & F3 & 30 & 0.867 \\
30 May 06 & F3 & 30 & 0.800 \\
6 Jun 06 & F3 & $90^{*}$ & $0.622^{*}$ \\
16 Jun 06 0 Jun 06 & F3 & $90^{*}$ & $0.622^{*}$ \\
27 Jun 06 & F3 & $90^{*}$ & $0.789^{*}$ \\
\hline & F3 & $90^{*}$ & $0.711^{*}$ \\
\hline
\end{tabular}

Data flagged with $\left(^{*}\right)$ are for $D$. retrocurva; all other data are for D. mendotae.

embryos represented $62 \%$ and $72 \%$ at F2 and $60 \%$ and $63 \%$ at $\mathrm{F} 3$.

\section{Daphnia birth rates and population growth}

Table 2 reports calculated net intrinsic growth rate $r$ for sampling intervals in all 3 years as well as estimated finite birth rates $B$ at beginning and end of each interval and death rate $d\left(\right.$ day $\left.^{-1}\right)$ calculated as the difference between birth and net growth:

$$
d=\text { mean } B-r
$$

In each year, the initial increases in Daphnia abundance are too rapid to be accounted for solely by estimated in situ birth rates, but by late May or June $r$ becomes substantially less than $B$, because of accelerating mortality rates. Outwash rate exceeds in situ mortality during May of 2004 and 2006, but not 2005. Neither birth rates nor $r$-values were elevated in 2005 
Table 2 Sampling intervals, intrinsic growth rate $(r)$, mean outwash rate $(\tau)$, finite birth rates $\left(B\right.$, day $\left.{ }^{-1}\right)$ at beginning and end of each interval and death rate $(d=\operatorname{mean} B-r)$

\begin{tabular}{lrlllr}
\hline Interval & $\begin{array}{l}r, \\
\text { day }^{-1}\end{array}$ & $\begin{array}{l}\tau, \\
\text { day }^{-1}\end{array}$ & $\begin{array}{l}B \\
\text { initial }\end{array}$ & $\begin{array}{l}B \\
\text { final }\end{array}$ & \multicolumn{1}{l}{$\begin{array}{l}\text { day }^{-1} \\
\text { 2004 }\end{array}$} \\
18 May-14 Jun & 0.211 & 0.219 & 0.001 & 0.038 & -0.192 \\
14 Jun-21 Jun & 0.100 & 0.158 & 0.038 & 0.400 & 0.119 \\
21-28 Jun & -0.186 & 0.087 & 0.400 & 0.146 & 0.459 \\
2005 & & & & & \\
9-16 May & 0.557 & 0.062 & 0.134 & 0.078 & -0.451 \\
16-23 May & 0.135 & 0.057 & 0.078 & 0.010 & -0.091 \\
23-31 May & -0.078 & 0.053 & 0.010 & 0.082 & 0.124 \\
31 May-6 Jun & -0.020 & 0.042 & 0.082 & 0.107 & 0.115 \\
6-10 Jun & 0.045 & 0.039 & 0.107 & 0.122 & 0.070 \\
10-20 Jun & -0.091 & 0.044 & 0.122 & 0.899 & 0.602 \\
20-27 Jun & 0.136 & 0.034 & 0.899 & 0.219 & 0.423 \\
2006 & & & & & \\
2-9 May & 0.457 & 0.070 & 0.197 & 0.529 & -0.094 \\
9-16 May & 0.259 & 0.204 & 0.529 & 0.049 & 0.030 \\
16-23 May & 0.053 & 0.264 & 0.049 & 0.193 & 0.068 \\
23-30 May & 0.044 & 0.156 & 0.193 & 1.154 & 0.630 \\
30 May-6 Jun & $0.616^{*}$ & 0.094 & ND* & $0.269^{*}$ & $-0.347^{*}$ \\
6-16 Jun & $0.060^{*}$ & 0.062 & $0.269^{*}$ & $0.499^{*}$ & $0.324^{*}$ \\
16-20 Jun & $-0.224^{*}$ & 0.048 & $0.499^{*}$ & $0.628^{*}$ & $0.788^{*}$ \\
20-27 Jun & $0.388^{*}$ & 0.070 & $0.628^{*}$ & $0.581^{*}$ & $0.217^{*}$ \\
\hline
\end{tabular}

ND, sample size too small for reliable birth rate estimation.

Data flagged with $\left(^{*}\right)$ are for $D$. retrocurva; all other data are for D. mendotae.

compared with the other years; net growth rates in 2006 were in fact greater than those of 2005 in many cases. It is clear, however, that $\tau$ was much lower in 2005 than in 2004 or 2006.

Leptodora was only sporadically encountered in May and June during 2004 and 2006; mean abundances were 28 individuals $\mathrm{m}^{-2}$ in 2004 and 41 individuals $\mathrm{m}^{-2}$ in 2006. In 2005, the population increased steadily from undetectable levels on 9 May to over 400 individuals $\mathrm{m}^{-2}$ on 20 June. During the same time, abundance ratios of $D$. mendotae to Leptodora declined from more than $5000: 1$ on 16 May to only $55: 1$ on 20 June. However, by solving eqn.7 for predation rate, $p$, it became clear that each Leptodora would have to consume on average 60 Daphnia per day $(\mathrm{SE}=10$, $n=4)$ for mortality caused by Leptodora alone to account for the decline of Daphnia after 23 May 2005.

Dreissena veligers exhibited interannual abundances that contrasted with those of Daphnia. Veligers became particularly abundant in June of 2004, but did not repeat that success in 2005 and 2006. The success in 2004 owes to a sustained period of positive net recruitment in excess of outwash that lasted from
Table 3 Calculated net recruitment rate $r$ for zebra mussel veligers into the water column of Ford Lake

\begin{tabular}{lrl}
\hline Interval & $r$, day $^{-1}$ & $\tau$, day $^{-1}$ \\
\hline 2004 & & \\
18 May-14 Jun & 0.306 & 0.219 \\
14-21 Jun & 0.217 & 0.158 \\
21-28 Jun & 0.064 & 0.087 \\
28 Jun-7 July & -0.090 & 0.053 \\
7-12 July & -0.342 & 0.057 \\
12-19 July & -0.407 & 0.064 \\
2005 & & \\
9-16 May & 0.489 & 0.062 \\
16-23 May & -0.236 & 0.057 \\
23-31 May & 0.210 & 0.053 \\
31 May-6 Jun & -0.127 & 0.042 \\
6-10 Jun & 0.095 & 0.039 \\
10-20 Jun & -0.036 & 0.044 \\
20-27 Jun & 0.039 & 0.034 \\
27 Jun-5 July & -0.185 & 0.046 \\
5-11 July & 0.220 & 0.044 \\
2006 2-9 May & & \\
9-16 May & 0.531 & 0.070 \\
16-23 May & 0.041 & 0.204 \\
23-30 May & -0.054 & 0.264 \\
30 May-6 Jun & 0.819 & 0.156 \\
6-16 Jun & -0.134 & 0.094 \\
16-20 Jun & -0.194 & 0.062 \\
20-27 Jun & -0.158 & 0.048 \\
27 Jun-5 July & -0.027 & 0.070 \\
5-11 July & 0.054 & 0.055 \\
\hline & & 0.035 \\
\hline
\end{tabular}

mid-May to the third week of June (Table 3). Moreover, outwash during the period of sustained recruitment in 2004 was considerably greater than in the later years. Mean $\tau$ from 15 May to 30 June was 0.174 day $^{-1}$ in 2004 compared with 0.045 day $^{-1}$ in 2005 and 0.118 day $^{-1}$ in 2006.

Elevated zebra mussel veliger abundance in 2004 followed a period of exceptional diatom production in 2004 that was not repeated in either 2005 or 2006 (Fig. 5). Planktonic diatom biovolume was dominated by Asterionella formosa Hass., and was calculated from cell counts and cell dimensions using standard geometric solids (Ferris \& Lehman, 2007). Diatoms were very successful in April 2004, and virtually depleted the lake of soluble silica, but sank out of the water column at the onset of thermal stratification in May.

\section{Fish stomach contents}

Bluegill ranged from 200 to $205 \mathrm{~g}$ fresh weight, and white bass ranged from 440 to $600 \mathrm{~g}$ fresh weight. 


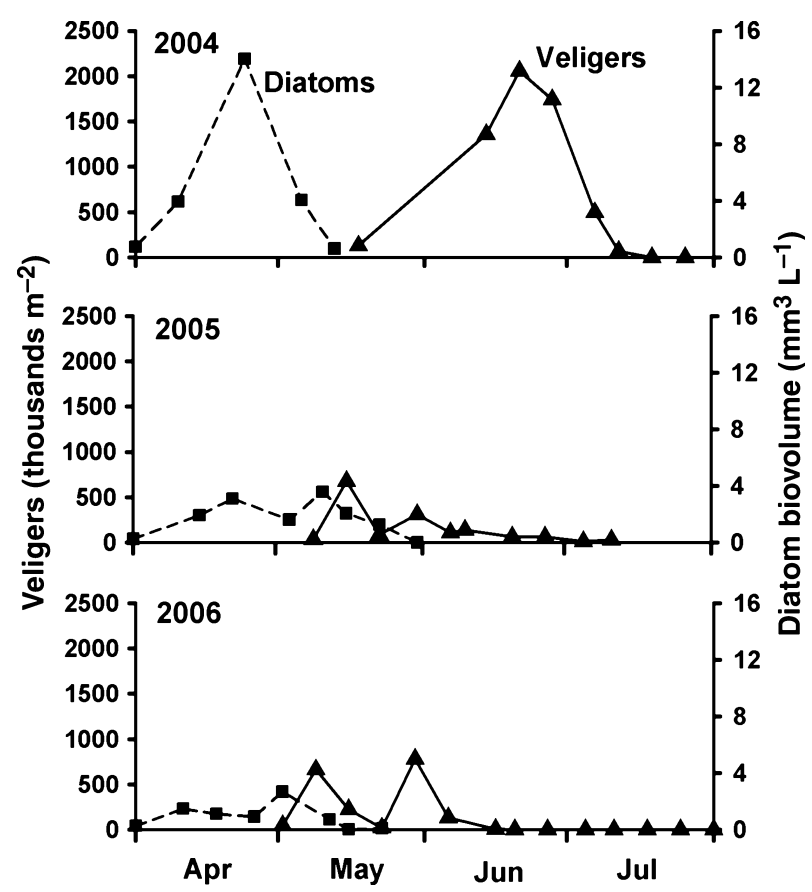

Fig. 5 Diatom biovolume (squares and dashed lines) and abundance of Dreissena veligers during 2004, 2005 and 2006.

Every fish had its stomach packed exclusively with adult D. mendotae and Leptodora.

\section{Historical river flow}

Inspection of historical flow data for the Huron River during May from 1985 to 2006 reveals that river discharge in 2005 was the fourth lowest for May of the past 22 years, and was $63 \%$ of the median discharge for May. Maximum historical discharge during May occurred in 2006 and was $73 \%$ greater than the median.

\section{Discussion}

Hydrology seems to act as a master variable affecting planktonic herbivore populations and the biologically-induced clear water phase in this urban impoundment. During 2005, outwash rates were sufficiently small compared with birth rates that positive net population growth could be sustained by Daphnia through most of May, triggering a clear water phase similar to those reported elsewhere (Lampert et al., 1986). Peak abundance of D. mendotae in 2005 exceeded 60 individuals $\mathrm{L}^{-1}$, based on lake mean depth of $4.3 \mathrm{~m}$. This is more than twice the threshold value of 30 individuals $\mathrm{L}^{-1}$ identified by Talling (2003) for development of clear water phases in lakes within the English Lake District, and is indicative of specific removal rates of phytoplankton of 1.2 day $^{-1}$, corresponding to the maximum specific growth rates of food organisms cited by Talling (2003). Thus, it seems that grazing by Daphnia alone was sufficient to account for the clear water phase in 2005, though other grazers, including zebra mussels, may have had contributing effects.

River flow during May 2005 was less than typical for the month, but values as low or lower during May have occurred about $20 \%$ of the time in recent history. Clear water phases may thus be predicted to develop within Ford Lake at least 1 year in five, if the past can be used to predict future patterns. On the other hand, if regional climate and changing land use patterns affect the seasonality of water runoff, there may be predictable corresponding changes in ecosystem response. Milder winters in the 21st century bring the prospect of earlier snow melt and runoff with temporal shifts in the timing of peak river flows. As these changes occur, we have a theoretical context for predicting their consequences for lake communities strongly controlled by hydrologic patterns.

Hydrology may also exert a strong, but indirect, effect on zebra mussel recruitment. The long sustained period of veliger production in 2004 followed a particularly large vernal diatom bloom. That bloom has been shown to be a consequence of slackened outwash in April, which permitted the diatoms to develop a large population and to deplete the soluble silica in the lake (Ferris \& Lehman, 2007). The large resulting biomass sank rapidly when thermal stratification was established in the first week of May. The diatoms provide a large potential food source for adult Dreissena, and may have contributed to a strong and sustained spawning period. Planktonic diatoms are a recognized food resource for zebra mussels (Holland, 1993), and the elevated fraction of organic matter in the seston, as occurs during a diatom bloom, has been implicated in generating increased net assimilation and scope for growth in zebra mussel populations (Madon et al., 1998; Schneider et al., 1998).

We chose to use Edmondson's original formulation for finite birth rate, $B$, rather than Paloheimo's instantaneous rate, $b$ (Paloheimo, 1974) because absence of demonstrable stable age distributions for 
D. mendotae violates the assumptions of Paloheimo's model and renders the predictions problematic. Estimates based on Edmondson's model are likewise inexact, but they provide a simple reference for comparison with estimated net growth rates, $r$. We failed to detect convincing evidence of egg mortality or inviability, and so it seems likely that accelerating death rates implied by the difference between $B$ and $r$ in June result from mortality on post-embryonic individuals. Elevated abundance of Leptodora in 2005 may be one contributing factor to the mortality rates. The excess of $r$ over $B$ in early May each year may represent recruitment from resting eggs.

Predation by Leptodora was insufficient to account for the mortality experienced by the Daphnia population after its peak abundance in May 2005. Wojtal et al. (2004) report maximum rates of predation on Daphnia to be 10 or fewer Daphnia per Leptodora per day. Herzig \& Auer (1990) reported maximum consumption rates on smaller Diaphanosoma as 12 individuals per Leptodora per day. These rates are too small by a factor of 5 to account for imputed mortality on Daphnia in Ford Lake. This conclusion parallels that of Pichlová \& Brandl (2003), who reported that Leptodora in the Slapy Reservoir could accelerate the summer decline of spring Cladocera, but they were not sufficient to cause species shifts. Instead, the high proportions of Daphnia juveniles in the population on many dates (Table 1) and plentiful adult Daphnia in fish stomachs suggest that visual planktivory by fish may be the likely agent of mortality in the case of Ford Lake.

Although Secchi disc transparency measurements testify to the dramatic clear water phase in Ford Lake during 2005 (Fig. 3), chl was not so consistently and dramatically reduced (Fig. 4). Inspection of zooplankton net collections had revealed the presence of colonial aggregations of Aphanizomenon trichomes at station F3 in 2005, in advance of their perennial presence lake-wide later in the summer. It is certainly well known that chl sequestered in large particles contributes less to water turbidity than does the same amount of pigment dispersed among many individual small particles. We tend to ascribe the disparity between transparency and chl levels at station F3 during May 2005 to the size distribution of chlorophyll-containing particles.

In conclusion, we recognize a flushing time of about 20 days as a critical threshold for the development of a grazing induced clear water phase in Ford Lake and other freshwater bodies like it. To the extent that future climate change alters the seasonality and magnitude of hydrologic variables, expectations about phytoplankton and zooplankton community responses could benefit from attention to the nonlinear responses of plankton communities at such thresholds.

\section{Acknowledgments}

E. Rourke provided field and laboratory assistance during 2004. R.P. received the Slater Scholarship for partial support of this work. This study was part of EPA STAR project R830653-010 and USDA CSREES 2006-02523.

\section{References}

Deevey G.B. (1960) The zooplankton of the surface waters of the Delaware Bay region. Bulletin of the Bingham Oceanographic Collection, 17, 54-86.

Edmondson W.T. \& Litt A.H. (1982) Daphnia in Lake Washington. Limnology and Oceanography, 27, 272-293.

Ferris J.A. \& Lehman J.T. (2007) Interannual variation in diatom bloom dynamics: roles of hydrology, nutrient limitation, sinking, and whole lake manipulation. Water Research, 41, 2551-2562.

Herzig A. \& Auer B. (1990) The feeding behaviour of Leptodora kindti and its impact on the zooplankton community of Neusiedler See (Austria). Hydrobiologia, 198, 107-117.

Hoffman J.C., Smith M.E. \& Lehman J.T. (2001) Perch or plankton: top-down control of Daphnia by yellow perch (Perca flavescens) or Bythotrephes cederstroemi in an inland lake? Freshwater Biology, 46, 759-775.

Holland R.E. (1993) Changes in planktonic diatoms and water transparency in Hatchery Bay, Bass Island Area, Western Lake Erie since the establishment of the zebra mussel. Journal of Great Lakes Research, 19, 617-624.

Lampert W. (1978) Climatic conditions and planktonic interactions as factors controlling the regular succession of spring algal bloom and extremely clear water in Lake Constance. Verhandlungen der internationale Vereinigung für theoretische und angewandte Limnologie, 20, 969-974.

Lampert W., Fleckner W., Rai H. \& Taylor B.E. (1986) Phytoplankton control by grazing zooplankton: a study of the spring clear-water phase. Limnology and Oceanography, 31, 478-490.

Lehman E.M. (2007) Seasonal occurrence and toxicity of Microcystis in impoundments of the Huron River, Michigan, USA. Water Research, 41, 795-802. 
Madon S.P., Schneider D.W., Stoeckel J.A. \& Sparks R.E. (1998) Effects of inorganic sediment and food concentrations on energetic processes of the zebra mussel, Dreissena polymorpha: implications for growth in turbid rivers. Canadian Journal of Fisheries and Aquatic Science, 55, 401-413.

Paloheimo J.E. (1974) Calculation of instantaneous birth rate. Limnology and Oceanography, 19, 692-694.

Pichlová R. \& Brandl Z. (2003) Predatory impact of Leptodora kindtii on zooplankton community in the Slapy Reservoir. Hydrobiologia, 504, 177-184.

Schneider D.W., Madon S.P., Stoeckel J.A. \& Sparks R.E. (1998) Seston quality controls zebra mussel (Dreissena polymorpha) energetics in turbid rivers. Oecologia, 117, 331-341.
Straškraba M. (2005) Reservoirs and other artificial water bodies. In: The Lakes Handbook (Eds P.E. O'Sullivan \& C.S. Reynolds ), pp. 300-328, Vol. 2. Blackwell, Oxford. Talling J.F. (2003) Phytoplankton-zooplankton seasonal timing and the 'clear-water phase' in some English lakes. Freshwater Biology, 48, 39-52.

Thornton K.W., Kimmel B.L. \& Payne F.E. (1990) Reservoir Limnology. Wiley, New York.

Wojtal A., Frankiewicz P., Wagner-Lotkowska I. \& Zalewski M. (2004) The evaluation of the role of pelagic invertebrate versus vertebrate predators on the seasonal dynamics of filtering Cladocera in a shallow, eutrophic reservoir. Hydrobiologia, 515, 123-135.

(Manuscript accepted 30 April 2007) 